\title{
Bloody Business: Multinational Investment in an Increasingly Conflict-Afflicted World
}

\section{Caroline Theresia Witte} Ph.D. awarded by Erasmus University Rotterdam, The Netherlands (January 2018)

\author{
BIG Question: \\ What determines multinational enterprises engagement \\ in conflict countries?
}

\section{Introduction}

When I started working on my Ph.D. dissertation in the summer of 2013, the Arab Spring, characterized by popular calls for democracy in several countries in the Arab world, had turned into an Arab Winter, characterized by horrific political conflicts. In the years that I developed the papers in my dissertation, the conflicts in Syria, Yemen and Libya only intensified. Globally, we have seen a large increase in political conflict from 35 conflicts in 2005 to 50 in 2015. ${ }^{1}$ This increase can of course be partially explained by the turmoil resulting from the Arab Spring, but conflict also increased in other parts of the word, such as Iraq, Nigeria or Ukraine. Interestingly enough, multinational enterprises (MNEs) do not seem so deterred by conflict and actively invest in conflict countries. Of all subsidiaries that MNEs opened in low, middle-income economies, $13 \%$ were actually in conflict countries, and $5 \%$ were even in war countries, defined as conflict countries with at least 1,000 battle-related deaths.

The research objective of my dissertation is to shed light on the opportunities for MNEs in conflict regions and to enhance our understanding of the MNE and conflict risk. Although the IB literature has paid considerable attention to MNEs investing in emerging markets and the risks associated with this, there has been somewhat limited attention to the relationship between conflict and MNEs. It has been mainly left to economists and political scientists, with the general idea that there lie very few opportunities in conflict areas for the private sector and multinationals in particular. However, global competition pushes firms to consider location options with relatively high political risk profiles, including those troubled by conflict and war. Accordingly, a better understanding of how conflict risk affects the operations of MNEs is much needed.

My thesis emphasizes that the assumption that political violence necessarily puts off investors is too simplistic. A considerable number of MNEs are attracted to conflict regions, showing that there are opportunities for firms to create and appropriate value whilst facing significant conflict-related risk. I even find that political conflict positively affects greenfield foreign direct investment (FDI) by the most diversified firms, suggesting that entry into conflict countries might allow firms to obtain a first-mover advantage if MNEs are able to absorb discontinuous risk. I also demonstrate that the continuity of the risk is an important factor influencing MNEs' entry strategies, so that exceptionally discontinuous risks, such as the risk of a terrorist attack, are so unpredictable that they do not affect FDI decisions. Finally, the findings of my thesis imply that wars can reduce the importance of home-host ties for current investment decisions.

\section{Main Themes: FDI, Political Conflict and Prosperity}

Ultimately, my dissertation concerns the relationships between political conflict, FDI and prosperity. In the triangle in Figure 1 , the relationships studied are depicted as two solid arrows. The largest part of my thesis is devoted to studying the relationship between FDI and violent political conflict. However, to study the factors which determine MNE's reaction to political 
conflict, it is necessary to understand how variation in conflict emerges in the first place. Therefore, the first paper of my dissertation focuses on explaining conflicts. To test both the effect of prosperity on conflict and the effect of conflict on FDI, I employ a variety of regression techniques on large panel datasets.

\section{Political Conflict}

Political conflict (Figure 1, top box) has two components. Whereas violent conflict, most notably civil war and to a lesser extent international conflicts, might be the most salient types of political conflict, in my dissertation, I also pay attention to civil resistance, the non-violent counterpart of armed conflict. Recently, we have seen that this type of conflict often leads to violent conflict (e.g., the Arab Spring in Syria) and can have large consequences for multinational enterprises (e.g., the anti-government protests in Hong Kong).

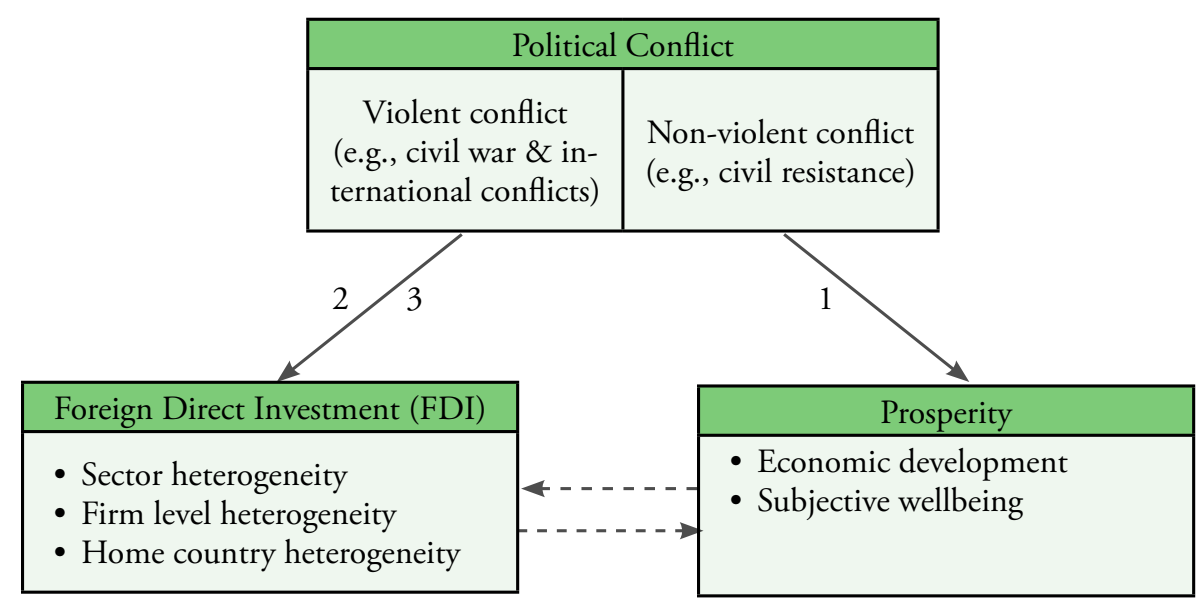

Figure 1. Illustration of the hypothesized political conflict, FDI and prosperity triangle

Note: The solid lines represent the relations studied in this dissertation, while the dashed lines correspond to relations established in the literature. The numbers indicate the papers of the dissertation in which the relationship is discussed.

\section{Foreign Direct Investment}

In terms of FDI (Figure 1, bottom left), I move beyond whether FDI flows are overall affected by political conflict and focus on different sources of heterogeneity that affect how FDI flows react to political conflict. These sources of heterogeneity include sector, firm and home country characteristics. Accordingly, I improve the understanding of the mechanisms that affect MNEs' investment opportunities in conflict-afflicted countries.

\section{Prosperity}

The final concept in the triangle is prosperity (Figure 1, bottom right), which focuses on healthy societies and thriving citizens. Whereas prosperity is often seen as a synonym for economic development, I am particularly concerned with the relationship with subjective wellbeing. This is particularly relevant in contexts where objective measures of development, like GDP growth and poverty measures, do not necessarily translate to an increase in life satisfaction. For example, in the period preceding the Arab Spring, many Arab countries, especially the ones where the uprisings were most intense, experienced a phenomenon called 'unhappy development', where rising income levels were accompanied by decreasing subjective wellbeing (Arampatzi et al., 2018).

\section{Main Findings and Results}

\section{Unhappy Rebels: The Role of Subjective Wellbeing in Civil Uprising}

This paper examines the antecedents of political conflict and is directly born out of my frustration with existing models of political conflict. These existing models tend to focus on objective factors such as GDP growth and ethnolinguistic fractualization, whilst these factors are unable to predict or explain the Arab Spring or some of the other recent conflicts. In the unhappy rebels' chapter, I ask whether wellbeing data can explain variation in non-violent conflict events. Particularly, I look at the number of anti-government protests and strikes around the globe. This type of conflict is prevalent around the world. Take for example, the protests at the beginning of the Arab Spring or those that preceded the violent conflict in Ukraine. The focus on subjective indicators is warranted by an increased discrepancy between developments in objective and subjective indicators. For example, whilst in most of parts of the Arab world income was growing, subjective wellbeing measures indicated a decrease in satisfaction with living standards.

My findings demonstrate that a decrease in subjective wellbeing can motivate citizens to engage in acts of civil resistance. This effect is largely the result of changes in satisfaction with living standards and the perceived capability to have a purposeful and meaningful life. These findings support the view that economic grievances can lead to peaceful uprisings. However, I find no effect of subjective wellbeing on violent political conflicts, which suggests that other factors such as the resources of rebels or the military power of the government play a more important role here.

Dodging Bullets: The Heterogeneous Effect of Political Violence on Greenfield FDI

In this chapter, I study the variation in how MNEs adjust their FDI in response to political violence. I argue that you would expect a negative effect for political conflict rather than for other types of political violence such as assassinations, political terror or terrorism. Political conflict has a higher impact on the 
operations of firms than political terror or assassinations (see Figure 2). In addition, it poses a more continuous risk than terrorism, meaning that it is relatively foreseeable and hence more likely to affect strategic decision-making. Hence, I argue that the average multinational will shy away from areas troubled by violent political conflict. However, a considerable number of MNEs invest in conflict countries anyways.

To study why firms invest in these conflict countries, I analyze the relationship between greenfield FDI flows and conflict for 90 developing countries over the period 2003 to 2012. I find that nationwide political conflict is negatively associated with total greenfield FDI, but this relationship is completely driven

\begin{tabular}{|c|c|c|c|}
\hline \multirow{2}{*}{\multicolumn{2}{|c|}{$\begin{array}{l}\text { Type of impact } \\
\text { Type of risk }\end{array}$}} & \multicolumn{2}{|l|}{ Level of impact } \\
\hline & & Low & High \\
\hline \multirow[t]{2}{*}{ O. } & $\begin{array}{l}\text { Discontinuous/ } \\
\text { Intermittent }\end{array}$ & Assassinations & Terrorism \\
\hline & Continuous & Political Terror & $\begin{array}{l}\text { Political conflict (e.g., civil } \\
\text { conflict or interstate war) }\end{array}$ \\
\hline
\end{tabular}

Figure 2. Different types of political violence, organized by level of impact and continuity

by decreased FDI flows into non-resource industries. In other words, whereas multinationals in the service and manufacturing industry decrease their investments in the case of conflict, I do not find any evidence that resource-related greenfield FDI decreases. Studying the mechanisms that could explain the insensitivity of resource FDI to political conflict, I find that this effect can largely be explained by the high profitability of natural resource extraction and geographic constraints on location choice.

In the non-resource sector, the least geographically diversified firms are most sensitive to conflict. Large MNEs active in many different countries are on the other hand not sensitive to political conflict. I find evidence that MNEs that are sufficiently internationalized are even attracted to conflict regions. This suggests that firms that enter into conflict countries might even increase earnings if MNEs are able to absorb discontinuous risk. As such, MNEs might want to consider entry into conflict countries - taking into account sector and firm attributes, despite the large level of risk posed, with the intention of obtaining a competitive advantage. Finally, other types of political violence, including intermittent violence in the form of terrorist acts and assassinations, or persistent but low-impact events, such as political terror, have no effect on the location choice decisions of multinational enterprises.

\section{When Political Instability Destroys Historical Ties}

While in the second paper, I look at the role of firm and sector level heterogeneity in the relationship between political conflict and FDI, in the third paper I turn to heterogeneity at the level of the MNE's home country. Whereas the effect of international wars on home-host ties is relatively well understood, this paper demonstrates how internal conflict - currently the dominant form of armed conflict- affects these relationships. Particularly, I look at the importance of previous colonial ties. It is well known that these ties can benefit firms from previous colonizer countries in a previous colony. In this paper, I ask: how is the value of home-host ties contingent on political conflict and instability? On the one hand, firms from previous colonizers might be better able to profit from the uncertainty and transparency than firms from countries without these ties. On the other hand, wars also pose a threat to their advantage, because the value of their relational resources could diminish quickly when conflict leads to institutional changes. I hypothesize that by increasing the risk within the institutional structure, small political conflict positively moderates the relationship between home-host ties and location attractiveness, whereas full-fledged wars and regime transitions, in which risk to the institutional structure dominates, erode the value of ties.

Examining location choice decisions in Sub-Saharan Africa, I find evidence that wars and institutional transitions indeed devaluate home-host ties, whereas small political conflict does not affect the value of ties. These results do not support the idea that connected firms can benefit more from the confusion caused by political conflict. In contrast, they seem to have more to lose and accordingly face considerable incentives to avoid the outbreak of wars.

\section{Contributions and Ilmplications for Practitioners}

Political conflict has become more prevalent in the last decades and with the consequences of global warming becoming more pronounced, the prospects of world peace are merely declining. My dissertation contributes to the existing literature on MNEs in developing countries by increasing our understanding of conflict risk for the MNE. A better understanding of the consequences of conflict helps firms prepare for conflict-related risks, possibly reducing the overall economic impact of conflict. My thesis' main contribution relates to the unpacking of conflict-related risks, and accordingly, this dissertation facilitates a better understanding of the interaction between risk and firm characteristics. I demonstrate that the continuity of the risk is an important factor influencing MNEs' entry strategies, 
so that exceptionally discontinuous risks, such as the risk of a terrorist attack, are so unpredictable that they do not affect FDI decisions. Yet, MNEs tend to avoid countries that are afflicted by armed conflict, a type of political violence that poses a relatively continuous type of risk and can have a large negative impact on a firm's profits.

I empirically show that whilst on average political violence that poses a discontinuous risk (e.g., terrorism) or has a low impact on the multinationals' operations (political terror) does not affect greenfield investments, political conflict is detrimental to MNEs. This is not surprising, because conflicts decrease the profitability of subsidiaries due to supply chain disruption and the risk of capital destruction. The average MNE might accordingly consider implementing strategies to minimize the probability of conflict. Although MNEs are unlikely to have a major influence on the outbreak of conflicts, they can nevertheless engage in voluntary actions that might decrease human suffering and could accordingly decrease conflict. Examples of such actions are providing adequate schooling and supporting small business development through skill trainings and microfinance.

Yet, the relationship between political conflict and FDI is heterogeneous. Several factors determine the sensitivity of FDI to political conflict, most notably:

1. The international profile of the MNE

2. Sector level economic rents and constraints on location choice

3. The MNE's geographic exposure to violence

4. The existence of home-host ties

Accordingly, my results emphasize that the assumption that political conflict necessarily depresses earnings and puts off investors is too simplistic. A considerable number of MNEs are attracted to conflict regions, showing that there are opportunities for firms to create and appropriate value whilst facing significant conflict-related risk. The finding that political conflict positively affects greenfield FDI by the most diversified firms, suggests that entry into conflict countries might even create strategic opportunities if MNEs are able to absorb discontinuous risk.

The findings in my thesis also imply that wars can reduce the importance of home-host ties for current investment decisions. These ties remain conducive to business dealings, but wars and institutional transitions can reduce the advantage that MNEs from countries with these ties have. This creates two separate sets of incentives for connected and unconnected MNEs. Connected MNEs are likely to benefit from the strengthening of a host government's state capacity and particularly from an increase in military power. A strong state could deter rebellion, whilst also decreasing the probability that insurgents win a conflict. MNEs could enhance host countries' state capacity by providing intelligence and financial resources, which can be employed to enhance military capacity. In addition, connected MNEs can lobby their home country governments into providing military support to the host country's government, which could deter insurgents. In contrast, unconnected MNEs might in the long run benefit from war and instability, because this could reduce the advantage of firms originating from a country with a tie to the host. By entering a country that is likely to go through an institutional transition in the near future and partnering up with the opposition party, MNEs can create a considerable political first-mover advantage.

Regarding economic and business policy, more attention should be given to the role of economic grievances that are subjective in nature. Here the case of 'unhappy development' merits special attention. Countries experiencing 'unhappy development' prosper in terms of objective indicators of development, but suffer in terms of subjective wellbeing. The Arab Spring was preceded by a period of such unhappy development. Hence, economic policies, such as trade agreements and corporate tax incentives, should not only be evaluated in terms of objective economic outcomes, but also in terms of their effect on subjective wellbeing. This also implies that there are opportunities for international business policy research to uncover how MNEs actually affect subjective wellbeing, including individuals' perceptions that they have the freedom to make something of their lives.

\section{References}

Arampatzi, E., Burger, M. J., lanchovichina, E., Röhricht, T., \& Veenhoven, R. 2018. Unhappy development: Dissatisfaction with Life on the Eve of the Arab Spring. Review of Income and Wealth, 64(S1): 80-113.

Pettersson, T., \& Wallensteen, P. 2015. Armed conflicts, 1946-2014. Journal of Peace Research, 52(4): 536-550.

\section{Endnotes}

1 Political conflict is defined as a contested incompatibility that concerns government and/or territory where the use of armed force between two parties, of which at least one is the government of a state, results in at least 25 battle-related deaths in one calendar year (Pettersson \& Wallensteen, 2015).

Caroline Witte (cwi.smg@cbs.dk) is an assistant professor of strategy and international management at the Department of Strategy and Innovation, Copenhagen Business School. She is mainly interested in strategic management in fragile economies. Caroline has a PhD from the Erasmus University Rotterdam and a MSc. in Economics and Business from the same institute. Caroline has also worked as an external consultant for the World Bank's Chief Economist Office for the Middle East \& North Africa. 